\title{
Karabük ili Safranbolu ilçesinde doğum sonu bakım hizmetlerinin kapsamı ve hizmet kullanımının belirleyicileri
}

\section{Determinants of scope and utilization of postnatal care services in Karabuk province Safranbolu district}

\author{
Raziye Özdemir ${ }^{1}$ Merve Karaçalı ${ }^{2}$ (D) \\ ${ }^{1}$ Karabük Üniversitesi, Sağlık Bilimleri Fakültesi İş Sağlığı ve Güvenliği Bölümü, Karabük, Türkiye \\ ${ }^{2}$ Eflani Toplum Sağlığı Merkezi, Karabük, Türkiye
}

Öz

Amaç: Anne ve bebek sağlığının geliştirilmesi, mortalite ve morbiditenin azaltılmasında doğum sonu bakım (DSB) hizmet kullanımı ve kapsamı önemli rol oynamaktadır. Bu çalışmanın amacı, Karabük ili Safranbolu ilçesinde DSB hizmetlerinin hizmet kullanımını ve kapsamını etkileyen faktörleri değerlendirmektir.

Gereç ve Yöntem: Kesitsel tipte planlanan bu çalışmada doğum sonu 42 günlük sürecini yeni tamamlayan 169 anne yer almaktadır. Kadınlara ulaşmak için aile hekimlerinin kayıtlarından yararlanılmıştır. Veriler, Sağlık Bakanlığı'nın Doğum Sonu Bakım Yönetim Rehberi temel alınarak hazırlanan bir soru formu aracılığı ile toplanmıştır. Anket formunda sosyodemografik özellikler, sağlık durumu, üreme sağlığıyla ilgili değişkenler, gebelik izlemlerinin sayısı ve niteliğiyle ilgili değişkenler sorgulanmıştır. Analizlerde ki-kare testi kullanılmıştır.

Bulgular: Doğum sonu hastanede izlenen kadınların düzeyi \%99,4'tür. Hastaneden taburcu olduktan sonra kadınların \%13'ü hiç izlenmemiştir. Tam izlem sıklığı \%26'dır. Doğum sonu hastaneden çıktıktan sonra DSB hizmeti almak için yapılan başvurular sırasıyla \%42,2 özel hastaneye, \%41,1 aile sağlığı merkezine, \%16,8 kamu hastanesine yapılmıştır. Doğum sonrası dönemde hiçbir kadın evde ziyaret edilmemiştir.

Sonuç: Çalışma DSB hizmet kullanımının düşük olduğunu ve DSB hizmetlerinde birinci basamağın rolü azalırken özel sektörün rolünün arttığını göstermektedir. DSB hizmetlerinin toplum tabanlı ve kapsayıcı olması anne ve bebek sağlığının geliştirilmesinin temel koşuludur.

Anahtar Sözcükler: Doğum sonu bakım, anne sağlığı, hizmet kullanımı, Safranbolu.

\begin{abstract} square test was used for analyses.

\footnotetext{
Yazışma Adresi: Raziye Özdemir

Karabük Üniversitesi, Sağlık Bilimleri Fakültesi İş Sağlığı ve

Güvenliği Bölümü, Karabük, Türkiye

E-mail: ozdemirr75@hotmail.com

Makalenin Geliş Tarihi: 19.07.2018 Kabul Tarihi: 09.10.2018
}

Aim: The utilization and scope of postnatal care (PNC) services play a fundamental role to improve maternal and infant health, decrease mortality and morbidity. The aim of this study is to assess the factors affecting the utilization and scope of PNC services in Safranbolu district of Karabuk province.

Material and Methods: In this cross-sectional study, 169 mothers who completed the 42-day postpartum period are included. In order to reach women, family physicians' records were used. The data were collected through a questionnaire based on the Ministry of Health's Postnatal Care Management Guide. In the questionnaire, variables related to sociodemographic characteristics, health status, reproductive health and variables related to number, quality and place of pregnant follow ups were questioned. Chi- 
Results: The level of women followed up at the hospital after delivery was $99.4 \% .13 \%$ of the women after being discharged from the hospital have not received PNC. The prevalence of women with completed postnatal follow-up was $26 \%$. Applications the women after being discharged from the hospital were made in order to get PNC services in $42.2 \%$ private hospitals, $41.1 \%$ family health centers and $16.8 \%$ public hospitals respectively. No women were visited at home during the postpartum period.

Conclusions: Study showed that the utilization of PNC services is low and while the role of primary health care for PNC is decreasing, the role of the private sector is increasing. The fact that PNC services are community-based and comprehensive, is a fundamental requirement for the improvement of maternal and infant health.

Keywords: Postnatal care, maternal health, utilization, Safranbolu.

\section{Giriş}

Doğum sonu bakım (DSB), anne ve bebeğin fiziksel, ruhsal ve sosyal yönden iyilik halinin sağlanması amacıyla sunulan, fizik muayene ve danışmanlık uygulamalarını içeren hizmetlerdir (1). Postpartum veya postnatal olarak adlandırılan dönem doğum sonu 12 ayı kapsamakla birlikte, özellikle ilk 42 gün anne ve bebeğin sağlık durumu açısından çok önem taşımaktadır (1). Dünyada her yıl 500 bin kadın, gebelik ve doğum komplikasyonları nedeniyle hayatını kaybetmektedir (2). Anne ve bebek ölümlerinin 2/3'ü doğumdan sonraki ilk iki gün içinde (2), beş yaş altı çocuk ölümlerinin \%40'ı ilk 28 gün içinde gerçekleşmektedir (1). Nitelikli doğum öncesi ve sonrası bakım sağlandığı takdirde neonatal bebek ölüm hızı \%36-67 oranında, anne ölüm hızı \%15 oranında düşürülebilmektedir $(3,4)$.

Sağlık hizmet kullanımı açısından temel belirleyici DSB hizmetlerinin her açıdan ulaşılabilir olmasıdır $(5,6)$. DSB hizmetleri farklı ülkelerde, çeşitli sosyal, ekonomik ve demografik faktörlerden etkilenmekte ve DSB hizmetinin nitelik ve niceliği değişiklik göstermektedir (7). Smith'in İngiltere'de DSB ile ilgili postpartum dönemdeki kadınların görüşlerini değerlendirdiği çalışmada, sağlık çalışanlarının ve eşin desteği, sosyal destek, pratisyenden ya da ebeden sağlık hizmeti alma, ev ziyaretleri, aile planlaması, bebeğin beslenmesi, lohusa ve anne sağlığı, doğum sonrası ağrı yönetimi, bakımın nasıl devam edeceği ile ilgili bilgilere ulaşabilme kadınları DSB hizmeti almaya yönlendiren en önemli faktörler olarak bildirilmiştir (8). Öte yandan pek çok gelişmemiş ülkede DSB hizmetlerinin kullanımı, ulaşılabilirliği, bilinirliği hala çok düşüktür (5). DSB hizmetlerinin ücretsiz olması da her zaman kadınların bu hizmetlerden yararlanacağı anlamına gelmemektedir.
Gebrehiwot ve arkadaşlarının Etiyopya'da 367 kadınla gerçekleştirdikleri çalışmada, DSB hizmetleri ülkede ücretsiz olmasına rağmen kadınların yalnızca \%32'sinin DSB kliniğini ziyaret ettikleri bildirilmiştir. Aynı çalışmada kadının ve eşin eğitim düzeyi ve işi, daha önce DÖB hizmeti almış olma, DSB hizmetlerinin varlığından haberdar olma gibi faktörlerin DSB hizmeti almayı etkilediği tespit edilmiştir. Özellikle hizmetin varlığından haberdar olmanın hizmet alımını 13 kata kadar etkilediği belirtilmiştir (9). Dennis ve arkadaşlarının çalışmasında ise Kenya'da daha önce başvuran bazlı ödemeye tabi olan doğum servislerinin ücretsiz hale getirilmesinden sonra antenatal ve postnatal kliniklerin kullanımında anlamlı bir artış olmadığı bildirilmiştir (10).

Türkiye Cumhuriyeti Sağlık Bakanlığı'nın Doğum Sonu Bakım Yönetim Rehberi'ne göre anneye doğumdan sonraki birinci günde üç kez (0-1, 1-6, 6-24 saatleri arası), 2-5 günler arası, 2. hafta ve 6 . haftada birer izlem olmak üzere toplam altı kez bakım verilmesi gerekmektedir (11). Türkiye Nüfus Sağılı Araştırması (TNSA) 2013 verilerine göre ülkemizde kadınların \%94'ü DSB almaktadır (12). Ülkemizde her ne kadar DSB hizmeti alma düzeyi yüksek bildirilse de genellikle annelere hastanede doğumu takiben lohusalık bakımı verilmekte ve sonrasında DSB alma düzeyi düşmektedir. Çatak ve arkadaşlarının Burdur'da DSB hizmetleri üzerine yaptıkları araştırmada, kadınların \%96'sına ilk 24 saatte doğumu gerçekleştirdikleri kurumda lohusalık izlemi yapıldığını, ancak yalnızca $\% 15$ 'inin üç kez DSB aldığı ve DSB hizmetlerinin nicelik, nitelik ve zamanlama açısından yetersiz olduğu belirtilmiştir (13). Altuntuğ ve Ege'nin Konya'da bir tıp fakültesinde yaptıkları müdahale çalışmasında gebeliğin son dönemi ve doğum sonrası dönemde sağlık eğitimi verdikleri 
kadınlarda kontrol grubuna göre taburculuğa hazır oluşun ve yaşam kalitesi düzeyinin olumlu olarak arttığı ve kendi bakımları, bebek bakımı, meme bakımı ve emzirmeye ait yaşadıkları güçlüklerin düzeyinin azaldığı saptanmıştırr (14).

$\mathrm{Bu}$ çalışmada, Karabük ili Safranbolu ilçesinde DSB hizmetlerinin kullanımını ve kapsamını etkileyen faktörlerin değerlendirilmesi amaçlanmıştır.

\section{Gereç ve Yöntem}

Kesitsel tipte planlanan bu çalışma, Karabük Üniversitesi'nden etik kurul onayı (26.10.2015, Sayı: 2015/10) ve Karabük Halk Sağlığı Müdürlüğü'nden (27.11.2015, Sayı: 5603) araştırma izinleri alındıktan sonra 2015-2016 yılları arasında Karabük İli Safranbolu İlçesinde gerçekleştirilmiştir. Türkiye İstatistik Kurumu'nun (TÜIK) 2014 yılı Adrese Dayalı Nüfus Kayıt Sistemi verilerine göre Safranbolu nüfusu 28981 erkek ve 29314 kadın olmak üzere toplam 58295'tir. Safranbolu'ya bağlı 60 köy bulunup, ilçe nüfusunun \%75,4'ü kentsel alanda yaşamaktadır. En küçük örnek hesaplaması Epi-Info-7 StatCalc Programı'nda evren TÜIK verilerine göre 2014'te Safranbolu'daki canlı doğum sayısı olan 683, prevalans TNSA 2013 sonuçlarına göre Batı Karadeniz Bölgesi'nde doğum sonu bakım sıklığı olan \%92,4 ve \%99 güven aralığı değerleriyle yapılan hesaplamada 146 olarak belirlenmiş, çalışmada doğum sonu 42 günlük sürecini yeni tamamlayan 169 anneye ulaşılmıştır. Kadınlara ulaşmak için aile hekimlerinin kayıtlarından yararlanılmıştır. Veriler, danışman öğretim üyesinin gözetiminde ve anketör eğitimleri tamamlandıktan sonra, Karabük Üniversitesi Sağlık Yüksekokulu Hemşirelik Bölümü Jinekoloji Hemşireliği İntörn Grubu tarafından kadınlarla evlerinde yüz yüze görüşme yoluyla toplanmıştır.

Veriler, Sağlık Bakanlığı'nın Doğum Sonu Bakım Yönetim Rehberi ve ilgili literatür temel alınarak hazırlanan bir soru formu aracılığı ile toplanmıştır. Anket formunda, yaş, eğitim, çalışma durumu, gelir algısı, aile tip gibi sosyodemografik değişkenlerin yanı sıra, toplam gebelik, düşük, ölü doğum, yaşayan çocuk sayısı, kullanılan doğum kontrol yöntemleri, son gebeliğin planlı olması gibi üreme sağlığıyla ilgili değişkenler ve gebelik izlemlerinin ve doğumun nerede yapıldığı, sayısı ve niteliğiyle ilgili değişkenler sorgulanmıştır. Araştırmada veriler dört izlem üzerinden sunulmuştur. Birinci izlem hastaneden çıkmadan $0-1,1-6,6-24$ saatleri arasında yapılan üç izlemin birleşimidir. Tam izlem, Sağlık Bakanlığı tarafından öngörülen aralıklarla hastane ve hastane dışındaki tüm izlemlerin herhangi bir kurumda yapılması olarak

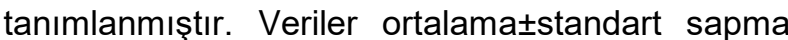
ve yüzde dağılım biçiminde özetlenmiştir. Analizde ki-kare testi kullanılmış ve $p<0,05$ ise anlamlı olarak kabul edilmiştir.

\section{Bulgular}

Çalışma grubunun yaş ortalaması $29,1 \pm 4,9$ (16-40) olup, üç kadın 20 yaşından küçük $(\% 1,8), 27$ kadın 35 yaşından büyüktür $(\% 16,0)$. Kadınların \%67,5' ilçe merkezinde yaşamaktadır ve \%62,7'si lise ve üzeri eğitime sahiptir. Kadınların \%21,3'ü, eşlerinin $\% 95,9^{\prime} u$ ücretli bir işte çalışmaktadır. Hanelerde kişi başı gelir ortalaması $746 \pm 482(92,9-2066,7)$ TL'dir.

Kadınların ortalama ilk evlilik yaşı $22,6 \pm 3,9$, ilk gebelik yaşı $23,9 \pm 3,9$ 'dir. Kadınların \%16,6'sı 20 'den küçük yaşta evlenmiş ve \%10,7'si 20 'den küçük yaşta gebe kalmıştır. Ortalama gebelik sayısı $2,1 \pm 1,0$, yaşayan çocuk sayısı ise 1,8 $\pm 0,9$ 'dur (Tablo-1). Kadınların \%21,3'ü en az bir düşük yaptırmıştır ve beş kadının $(\% 1,8)$ ölü doğum öyküsü vardır.

Kadınların gebe olduğunu öğrendiği hafta ortalama $4,7 \pm 1,5$ olup, \%46,2'si gebeliğini ilk dört hafta içinde öğrenmiştir. Doğum öncesi izlem sayısı ortalama $5,3 \pm 1,3 \quad(0-8)$ olarak saptanmıştır. Gebeliği ile ilgili hizmet almak üzere sağlık kuruluşlarına yapılan toplam başvuruların \%42'si özel hastaneye, \%29,8'i ASM'ye, \%28,2'si kamu hastanesine yapılmıştır. Kadınların \%26,6'sı gebeliği boyunca ASM'ye hiç gitmemiştir. Bir kadın, gebeliği boyunca hiçbir sağlık kuruluşunda gebeliğine ilişkin hizmet almadığını belirtmiştir. Çalışma grubunun \%94,1'i tetanoza karşı bağışıklanmış, on kadın aşı olmayı reddetmiştir. Tetanoz aşısı olmayı kabul etmeyen kadınların beşi en az bir kez ASM'ye başvurmuştur. Gebelikleri döneminde 25 kadında komplikasyon gelişmiştir (ASM'de hiç izlemi olmayanların $\% 20$ 'sini, en az bir izlemi olanların \%12,9'unu oluşturmaktadır). Doğum öncesi izlemlerde kadınlara en fazla anne sütü ve emzirme $(\% 79,8)$, en az gebelikte teratojenik ajanlar $(\% 51,8)$ konusunda danışmanlık verilmiştir (Tablo-2). 
Tablo-1. Çalışma grubunun sosyodemografik ve doğurganlık özellikleri $(n=169)$.

\begin{tabular}{|c|c|c|}
\hline Değişken & $\mathbf{n}$ & $\%$ \\
\hline \multicolumn{3}{|l|}{ Yaş } \\
\hline 24 yaş ve altı & 31 & 18,3 \\
\hline $25-34$ & 111 & 65,7 \\
\hline 35 yaş ve üzeri & 27 & 16,0 \\
\hline \multicolumn{3}{|l|}{ Yerleşim yeri } \\
\hline Merkez & 114 & 67,5 \\
\hline Köy & 55 & 32,5 \\
\hline \multicolumn{3}{|l|}{ Öğrenim düzeyi } \\
\hline İlkokul ve altı & 30 & 17,8 \\
\hline Ortaokul & 33 & 19,5 \\
\hline Lise & 50 & 29,6 \\
\hline Üniversite & 56 & 33,1 \\
\hline \multicolumn{3}{|l|}{ Çalışma durumu } \\
\hline Çalışmıyor & 133 & 78,7 \\
\hline Çalışıyor & 36 & 21,3 \\
\hline \multicolumn{3}{|l|}{ Eşin öğrenim düzeyi } \\
\hline İlkokul ve altı & 20 & 11,8 \\
\hline Ortaokul & 23 & 13,6 \\
\hline Lise & 61 & 36,1 \\
\hline Üniversite & 65 & 38,5 \\
\hline \multicolumn{3}{|l|}{ Eşin çalışma durumu } \\
\hline Çalışmıyor & 7 & 4,1 \\
\hline Çalışıyor & 162 & 95,9 \\
\hline \multicolumn{3}{|l|}{ Gelir algısı } \\
\hline Yetiyor & 100 & 59,2 \\
\hline Zor yetiyor & 55 & 32,5 \\
\hline Yetmiyor & 14 & 8,3 \\
\hline \multicolumn{3}{|l|}{ Aile tipi } \\
\hline Çekirdek & 153 & 90,5 \\
\hline Geniş & 16 & 9,5 \\
\hline Doğurganlık özellikleri & Ort $\pm S S$ & Minimum-maksimum \\
\hline İlk evlilik yaşı & $22,6 \pm 3,9$ & $13-34$ \\
\hline İlk gebelik yaşı & $23,9 \pm 3,9$ & $16-35$ \\
\hline Toplam gebelik sayısı & $2,1 \pm 1,0$ & $1-6$ \\
\hline Toplam doğum sayısı & $1,8 \pm 0,9$ & $1-6$ \\
\hline Yaşayan çocuk sayısı & $1,8 \pm 1,8$ & $1-5$ \\
\hline
\end{tabular}


Tablo-2. Doğum öncesi döneme ilişkin bulgular.

\begin{tabular}{|c|c|c|}
\hline Değişken & $\mathbf{n}$ & $\%^{*}$ \\
\hline \multicolumn{3}{|l|}{ Gebeliğin öğrenildiği hafta } \\
\hline 4. hafta ve daha önce & 78 & 46,2 \\
\hline 5-9 hafta & 91 & 53,8 \\
\hline Toplam & 169 & 100,0 \\
\hline \multicolumn{3}{|l|}{ Gebeliği ile ilgili hizmet almak üzere sağlık kuruluşuna başvuru sayısı } \\
\hline Yok & 1 & 0,6 \\
\hline $1-3$ & 8 & 4,7 \\
\hline $4-5$ & 59 & 34,9 \\
\hline 6 ve daha fazla & 101 & 59,8 \\
\hline Toplam & 169 & 100,0 \\
\hline \multicolumn{3}{|l|}{ Toplam başvuruların sağlık kuruluşuna göre dağılımı } \\
\hline $\mathrm{ASM}^{* *}$ & 277 & 29,8 \\
\hline Özel hastane & 391 & 42,0 \\
\hline Kamu hastanesi & 262 & 28,2 \\
\hline Toplam & 930 & 100,0 \\
\hline \multicolumn{3}{|l|}{ ASM'de izlem durumu } \\
\hline ASM'de hiç izlem yok & 45 & 26,6 \\
\hline ASM'de en az bir izlem var & 124 & 73,4 \\
\hline Toplam & 169 & 100,0 \\
\hline \multicolumn{3}{|l|}{ Özel hastanede izlem } \\
\hline Özel hastanede hiç izlemi yok & 65 & 38,5 \\
\hline Özel hastanede en az bir izlemi var & 104 & 61,5 \\
\hline Toplam & 169 & 100,0 \\
\hline \multicolumn{3}{|l|}{ Kamu hastanesinde izlem } \\
\hline Hiç izlem yok & 10 & 5,9 \\
\hline En az bir izlem var & 159 & 94,1 \\
\hline Toplam & 169 & 100,0 \\
\hline \multicolumn{3}{|l|}{ Tetanoza karşı aşılama*** } \\
\hline Evet & 159 & 94,1 \\
\hline Hayır & 10 & 5,9 \\
\hline Toplam & 169 & 100,0 \\
\hline \multicolumn{3}{|l|}{ Gebelikte ilaç desteği } \\
\hline D vitamini + Demir preparatı + Folik asit & 154 & 91,1 \\
\hline Yalnız demir preparatı & 3 & 1,8 \\
\hline Yalnız D vitamini & 3 & 1,8 \\
\hline Kullanmayan & 9 & 5,3 \\
\hline Toplam & 169 & 100,0 \\
\hline \multicolumn{3}{|l|}{ Gebelik sırasında komplikasyon } \\
\hline Gelişen $^{\dagger}$ & 25 & 14,8 \\
\hline Gelişmeyen & 144 & 85,2 \\
\hline Toplam & 169 & 100,0 \\
\hline \multicolumn{3}{|l|}{ Danışmanlık konusu ${ }^{\dagger \dagger}$} \\
\hline Anne sütü ve emzirme & 134 & 79,8 \\
\hline Bebek bakımı ve izlemleri & 106 & 63,1 \\
\hline Doğum yerinin ve doğum şeklinin planlanması & 105 & 62,5 \\
\hline Aile planlaması & 101 & 60,1 \\
\hline Beslenme & 100 & 59,5 \\
\hline Gebelikte olabilecek yakınmalar & 92 & 54,8 \\
\hline Gebelikte tehlike belirtileri & 92 & 54,8 \\
\hline Gebelikte teratojenik ajanlar (alkol, sigara, radyasyon, ilaçlar, enfeksiyonlar) & 89 & 53,0 \\
\hline Hijyen ve genel vücut bakımı & 87 & 51,8 \\
\hline
\end{tabular}


Tablo-3. Doğum ve doğum sonu dönem ile ilgili bulgular.

\begin{tabular}{|c|c|c|}
\hline Değişken & $\mathbf{n}$ & $\%^{*}$ \\
\hline \multicolumn{3}{|c|}{ Doğum gerçekleştiği sağlık kuruluşu } \\
\hline Özel hastane & 105 & 62,1 \\
\hline Kamu hastanesi & 64 & 37,9 \\
\hline Toplam & 169 & 100,0 \\
\hline \multicolumn{3}{|l|}{ Doğum şekli } \\
\hline Sezaryen & 118 & 69,8 \\
\hline Normal vajinal doğum & 51 & 30,2 \\
\hline Toplam & 169 & 100,0 \\
\hline \multicolumn{3}{|c|}{ Vajinal doğumda epizyotomi uygulaması } \\
\hline Var & 49 & 96,1 \\
\hline Yok & 2 & 3,9 \\
\hline Toplam & 51 & 100,0 \\
\hline \multicolumn{3}{|c|}{ Doğum sonu izlem zamanına göre izlenen kadın sayısı } \\
\hline İlk 24-48 saat (hastanede) & 168 & 99,4 \\
\hline $2-5$ gün & 122 & 72,2 \\
\hline İkinci hafta & 65 & 40,5 \\
\hline Altıncı hafta & 109 & 64,5 \\
\hline \multicolumn{3}{|c|}{ Doğum sonu hastaneden çıktıktan sonra yapılan izlem sayısı } \\
\hline Yok & 22 & 13,0 \\
\hline $1 \mathrm{kez}$ & 38 & 22,5 \\
\hline $2 \mathrm{kez}$ & 40 & 23,7 \\
\hline 3 ve üzeri & 69 & 40,8 \\
\hline Toplam & 169 & 100,0 \\
\hline \multicolumn{3}{|c|}{ Toplam başvuruların sağlık kuruluşuna göre dağılımı** } \\
\hline Aile sağlığı merkezi & 147 & 41,1 \\
\hline Özel hastane & 151 & 42,2 \\
\hline Kamu hastanesi & 60 & 16,8 \\
\hline Toplam & 358 & 100,0 \\
\hline \multicolumn{3}{|l|}{ Aile sağlığı merkezinde izlem* } \\
\hline Hiç izlem yok & 77 & 45,6 \\
\hline En az bir kez izlem & 92 & 54,4 \\
\hline Toplam & 169 & 100,0 \\
\hline \multicolumn{3}{|l|}{ Özel hastanede izlem ${ }^{\star *}$} \\
\hline Hiç izlem yok & 84 & 49,7 \\
\hline En az bir kez izlem & 85 & 50,3 \\
\hline Toplam & 169 & 100,0 \\
\hline \multicolumn{3}{|l|}{ Kamu hastanesinde izlem ${ }^{\star *}$} \\
\hline Hiç izlem yok & 72 & 42,6 \\
\hline En az bir kez izlem & 97 & 57,4 \\
\hline Toplam & 169 & 100,0 \\
\hline \multicolumn{3}{|l|}{ Doğum sonu komplikasyon } \\
\hline Gelişen*** & 3 & 1,8 \\
\hline Gelişmeyen & 166 & 98,2 \\
\hline \multicolumn{3}{|l|}{ Doğum sonu danışmanlık } \\
\hline Bağışıklama takvimi & 135 & 79,9 \\
\hline Anne sütü ve emzirme & 87 & 51,5 \\
\hline Bebek bakımı & 71 & 42,0 \\
\hline Beslenme & 68 & 40,2 \\
\hline Doğum sonu tehlike belirtileri & 60 & 35,5 \\
\hline Aile planlaması & 51 & 30,2 \\
\hline
\end{tabular}

* Sütun yüzdesi,

** Hastaneden çıktıktan sonra yapılan izlemler üzerinden hesaplandı ${ }^{* * *}$ Doğum sonu kanama ****Birden fazla seçenek işaretlenmiştir. 
Tablo-3'te çalışma grubunun doğum ve doğum sonu dönemleri ile ilgili bazı özellikleri sunulmuştur. Doğumların \%62,1'i özel, \%37,9'u kamu hastanesinde gerçekleşmiştir. Sezaryen doğumların düzeyi $\% 69,8$ 'dir. Normal vajinal doğumların \%96,1'inde epizyotomi açılmıştır.

Kadınların \%13'ü doğum sonu hastaneden taburcu olduktan sonra hiç izlenmemiş, \%22,5'i bir kez, \%23,7'si iki kez, \%40,8'i üç ve daha fazla sayıda izlenmiştir. Sağlık Bakanlığının öngördüğü zaman aralıklarına uygun olarak izlenen kadın sayısı yalnızca 44'tür $(\% 26,6)$. Hastaneden çıktıktan sonra yapılan toplam sağlık kuruluşu başvurularının \%42,2'si özel hastaneye, \%41,1'i ASM'ye, \%16,8'i ise kamu hastanesine yapılmıştır. ASM'de izlem düzeyi, doğum sonu 2-5. günlerde $\% 30,5$, ikinci haftada \%33,3, altıncı haftada $\% 57,1$ 'dir. Doğum sonrasında hiçbir kadın evde ziyaret edilmemiştir. Annelere en fazla çocukluk çağı bağışıklama takvimi $(\% 79,9)$ ve emzirme $(\% 51,5)$ konusunda bilgi verilmiştir (Tablo-3).

Yenidoğanların \%51,8'inin cinsiyeti kızdır. Konjenital anomaliye sahip bir, düşük doğum ağırlığı olan dokuz bebek dünyaya gelmiştir. Gelecekte başka çocuk sahibi olmayı düşünmeyen kadınların yüzdesi 60,7 , modern yöntemle korunmaya başlayanların ise 46,7'dir. Başka çocuk sahibi olmak istemeyen kadınların \%5,8'i, tüm kadınların \%5,3'ü gelecekte AP yöntemi olarak geri çekme yöntemi kullanacağını; başka çocuk sahibi olmak istemeyen kadınların \%5,8'i, tüm kadınların $\% 8,3$ 'ü gelecekte hangi yöntemi kullanacağı konusunda kararsız olduğunu bildirmiştir. Annelerin $\% 4,7$ 'si bebeğini emzirmemektedir. Emziren annelerin \%34,3'ü altıncı aydan önce, \%60,9'u altıncı ayda, \%2,4'ü 7-11. aylarda bebeği için ek gıdalara başlayacağını belirtmiştir.

Doğumdan sonra annenin hastanede kaldığı süre içinde sağlık durumuna yönelik ölçüm ve kontroller kan ve idrar tetkiki dışında büyük ölçüde yapılmıştır. Ancak hastaneden çıktıktan sonra yapılan işlemlerin sıklığının çok düştüğü görülmektedir (Tablo-4).

Doğumdan sonra anne hastaneden taburcu olduktan sonra üç ve daha fazla izlenmesini, doğum öncesi dönemde dört ve daha fazla sayıda izlem yapılması, doğum öncesi dönemde anneye beşten fazla başlıkta bilgi verilmesi ve doğumun özel hastanede gerçekleşmesi olumlu yönde etkilemektedir (sırasıyla $p=0,010, p<0,001, p=$ $0,015)$. Doğum sonu izlem sayısı ile incelenen diğer değişkenler arasında anlamlı ilişki saptanmamıştır.

Tablo-4. Doğum sonu anneye yönelik yapılan işlemler.

\begin{tabular}{lrrrrrrrrr}
\hline & \multicolumn{2}{c}{$\begin{array}{c}\text { Illk 24-48 saat } \\
\text { (Hastanede) }\end{array}$} & \multicolumn{2}{c}{ 2-5 gün } & \multicolumn{2}{c}{ 2. hafta } & \multicolumn{2}{c}{ 6. hafta } \\
\cline { 2 - 10 } & $\mathbf{n}$ & \% & $\mathbf{n}$ & $\%$ & $\mathbf{n}$ & $\%$ & $\mathbf{n}$ & \% \\
\hline Ateş ölçümü & 160 & 95,2 & 50 & 29,6 & 5 & 3,0 & 7 & 4,1 \\
Kan basıncı ölçümülem & 165 & 97,6 & 55 & 32,5 & 6 & 3,6 & 8 & 4,7 \\
Fundus yüksekliğinin kontrolü & 159 & 94,1 & 43 & 25.4 & 4 & 2,4 & 5 & 3,0 \\
Kanama kontrolü & 162 & 95,9 & 40 & 23,7 & 4 & 2,4 & 4 & 2,4 \\
Sezaryen insizyonu/epizyotomi & 145 & 85,8 & 29 & 17,2 & 3 & 1,8 & 2 & 1,2 \\
kontrolü ve bakımı & 89 & 52,7 & 17 & 10,1 & 0 & - & 0 & - \\
Kan tetkiki & 70 & 41,4 & 11 & 6,5 & 0 & - & 0 & - \\
İdrar tetkiki & & & & & & & & \\
\hline
\end{tabular}


Tablo-5. Doğum sonu izlem sayısı ile ilişkili faktörler.

\begin{tabular}{|c|c|c|c|c|c|c|}
\hline \multirow[b]{2}{*}{ Değişken } & \multicolumn{2}{|c|}{ 0-2 izlem } & \multicolumn{2}{|c|}{3 ve üzeri izlem } & \multirow[b]{2}{*}{ Ki-kare } & \multirow[b]{2}{*}{$\mathbf{p}$} \\
\hline & $\mathbf{n}$ & $\%^{*}$ & $\mathbf{n}$ & $\%^{*}$ & & \\
\hline \multicolumn{7}{|l|}{ Yaş } \\
\hline 20 yaş ve altı & 4 & 80,0 & 1 & 20,0 & 3,332 & 0,504 \\
\hline $21-25$ & 24 & 64,9 & 13 & 35,1 & & \\
\hline $26-30$ & 34 & 51,5 & 32 & 48,5 & & \\
\hline $31-35$ & 25 & 61,0 & 16 & 39,0 & & \\
\hline 35 yaş ve üzeri & 13 & 65,0 & 7 & 35,0 & & \\
\hline \multicolumn{7}{|l|}{ Yerleşim yeri } \\
\hline İlçe merkezi & 67 & 58,8 & 47 & 41,2 & 0,023 & 0,879 \\
\hline Köy & 33 & 60,0 & 22 & 40,0 & & \\
\hline \multicolumn{7}{|l|}{ Öğrenim düzeyi } \\
\hline İlkokul ve altı & 21 & 70,0 & 9 & 30,0 & 1,864 & 0,394 \\
\hline Ortaokul & 18 & 54,5 & 15 & 45,5 & & \\
\hline Lise ve üzeri & 61 & 57,5 & 45 & 42,5 & & \\
\hline \multicolumn{7}{|l|}{ Çalışma durumu } \\
\hline Çalışıyor & 23 & 63,9 & 13 & 36,1 & 0,421 & 0,516 \\
\hline Çalışmıyor & 77 & 57,9 & 56 & 42,1 & & \\
\hline \multicolumn{7}{|l|}{ Geçim algısı } \\
\hline Yetiyor & 55 & 55,0 & 45 & 45,0 & 1,764 & 0,184 \\
\hline Zor yetiyor ve yetmiyor & 45 & 65,2 & 24 & 34.8 & & \\
\hline \multicolumn{7}{|l|}{ Aile tipi } \\
\hline Çekirdek & 89 & 58,2 & 64 & 41,8 & 0,671 & 0,413 \\
\hline Geniş & 11 & 68,8 & 5 & 31,2 & & \\
\hline \multicolumn{7}{|l|}{ Toplam doğum sayısı } \\
\hline $1-2$ & 83 & 58,9 & 58 & 41,1 & 0,033 & 0,856 \\
\hline 3 ve üzeri & 17 & 60,7 & 11 & 39,3 & & \\
\hline \multicolumn{7}{|c|}{ Son doğumun istenme durumu } \\
\hline İsteyen & 90 & 58,1 & 65 & 41,9 & 0,949 & 0,330 \\
\hline İstemeyen & 10 & 71,4 & 4 & 28,6 & & \\
\hline \multicolumn{7}{|l|}{ Doğum öncesi izlem sayısı } \\
\hline 3 ve daha az & 9 & 100,0 & 0 & 0,0 & 6,559 & 0,010 \\
\hline 4 ve üzeri & 91 & 56,9 & 69 & 43,1 & & \\
\hline \multicolumn{7}{|l|}{ Doğum öncesi danışmanlık } \\
\hline 5 ve altında başlıkta eğitim & 64 & 78,0 & 18 & 22,0 & 23,495 & 0,000 \\
\hline 6 ve üzeri başlıkta eğitim & 36 & 41,4 & 51 & 58.6 & & \\
\hline \multicolumn{7}{|l|}{ Doğumun gerçekleştiği yer } \\
\hline Kamu hastanesi & 46 & 70,8 & 19 & 29,2 & 5,881 & 0,015 \\
\hline Özel hastane & 54 & 51,9 & 50 & 48,1 & & \\
\hline \multicolumn{7}{|l|}{ Doğum şekli } \\
\hline Normal vajinal doğum & 33 & 64,7 & 18 & 35,3 & 0,926 & 0,336 \\
\hline Sezaryen & 67 & 56,8 & 51 & 43,2 & & \\
\hline \multicolumn{7}{|l|}{ Yenidoğanın cinsiyeti } \\
\hline $\mathrm{K} \mathrm{Iz}$ & 50 & 56,8 & 38 & 43,2 & 0,421 & 0,516 \\
\hline Erkek & 50 & 61,7 & 31 & 38,3 & & \\
\hline
\end{tabular}

* Satır yüzdesi 


\section{Tartışma}

Karabük ili Safranbolu ilçesinde DSB hizmetlerinin kullanımını ve kapsamını etkileyen faktörleri değerlendirmek amacıyla gerçekleştirilen bu çalışma, Sağlıkta Dönüşüm Programı uygulanmaya başladıktan sonra bir sağlık kurumunda değil alanda yürütülmüş az sayıdaki araştırmadan biridir. Çalışmanın başlıca dikkat çeken yönü, doğum öncesi ve doğum sonu bakım hizmetlerinde kritik konumda olan birinci basamağın işlevi azalırken, hastanelerin, özellikle de özel sektörün ağırlığının arttığını yansıtması ve bakım hizmetlerinin kadınların talebine dayalı yürütüldüğünü göstermesidir.

Doğumdan sonra kanama ve enfeksiyon anne ölümlerinin çoğunluğundan, erken doğum, asfiksi ve ağır enfeksiyonlar da bir hafta içindeki yeni doğan ölümlerinin üçte ikisinden sorumludur (1). Ülkemizde anne ölümlerinin \%29,8'i doğumdan sonraki ilk 24 saatte, \%34,3'ü ilk 48 saatte gerçekleşmektedir (15). Doğum sonrası ilk saatlerde ve günlerde uygun bakım verilmesiyle, bu ölümlerin büyük çoğunluğunu önlenebilir (2). Çalışmada, tüm kadınların hastanede doğum yapmasına bağı olarak doğum sonrası hastane izlemleri \%99,4 gibi yüksek bir değerde bulunmuştur. TNSA 2013'te kadınların \%83,6'sı doğumu takiben ilk 24 saat içinde olmak üzere \%93,1'i en az bir kez doğum sonrası bakım aldığını belirtmiştir (12). Bununla birlikte çalışmada hastaneden çıktıktan sonra yapılması gereken 2-5 gün, ikinci ve altıncı hafta izlemlerinin ve bu izlemlerde yapılması gereken muayene ve tetkiklerin düzeyinin çok yetersiz olduğu görülmüştür. Hastaneden taburcu olduktan sonra kadınların \%13'ü hiç izlenmemiş, \%22,5'ine tek izlem, \%23,7'sine iki, \%40,8'ine üç ve daha fazla izlem yapılmıştır. Çatak ve ark. 2009 yılında Burdur'da doğum sonu izlemleri değerlendirdikleri araştırmalarında kadınların \%4,8'inin hastaneden çıktıktan sonra hiç izlenmediği, \%15,2'sinin ise üç kez DSB aldığı bildirilmiştir (13). Burdur ile karşılaştırıldığında Safranbolu'da hastaneden çıktıktan sonra doğum sonu bakım hizmeti almayanların sıklığının daha yüksek olması DSB hizmetlerine erişim ve kullanım ile ilgili sorunları yansıtırken, üç kez izlenen kadınların daha fazla olması izlemlerin büyük bölümünün gerçekleştiği özel hastaneden hizmet alımının kolaylığına bağlanabilir.
Dünya Sağlık Örgütü'nün (DSÖ), 2010 yııında revize edilen doğum sonrası bakımlarla ilgili teknik rehberinde bu izlemlerin amacı kadın ile bebeğin sağlığını korumak ve geliştirmek, yalnızca fiziksel sağlık değil sosyal intiyaçlarını da sağlamak için aile ve toplum desteğini geliştirmek olarak ifade edilmiştir (2). DSÖ'nün rehberlerinde önerilen izlem sayısı daha az olmakla birlikte izlem zamanları SB rehberiyle uyumludur $(1,2)$. $\mathrm{Bu}$ rehberlerde annelere ve ailelerine evde, kendileri ve yenidoğanları için emzirme ve olası tehlikelerle ilgili bilgi verilmesi, özellikle ruh sağlığıyla ilgili sorunların değerlendirilmesi önerilmiştir (1, 2). DSÖ rehberlerinin yanı sıra Sağlık Bakanlığı rehberlerinde evde ziyaret doğum sonrası izlemlerde önerildiği ve bunun anne ve bebek sağlığı açısından önemi vurgulandığı halde $(1,2$, 11), bu çalışmada ne doğum öncesi ne de lohusalık döneminde kadınların evde ebe tarafından hiç ziyaret edilmemiştir. Kadınların fiziksel, ruhsal ve sosyal yönden sağlık durumunu değerlendirmek için çok önemli bir fırsat olan evde ziyaretlerinin gerçekleştirilmemesi, birinci basamak sağlık hizmetlerinin temel özelliklerinden olan toplumu tanıma ve sürekli hizmet ilkeleri ile de çelişmektedir. (8).

Doğum sonrası dönem kadınların fiziksel ve ruhsal bakımdan en hassas oldukları dönemdir. Dolayısıyla bu dönemde kadın kendini güvende ve rahat hissetmek ister ve bu da ancak kadının kendi ev ortamı içinde sağlanabilir (16). Kenny ve ark. Avustralya'da kadınların doğum sonrası dönemde bakım tercihleri üzerine yaptıkları çalışmada evde bakım alan kadınların hastanede bakım alan kadınlara göre doğum sonrası bakım hizmetlerinden daha memnun oldukları tespit etmişlerdir (17). Erenel ve Eroğlu'nun Ankara'da doğum sonrası ilk altı aylık dönemde annelere ev ziyareti aracılığıyla verdikleri emzirme eğitimini değerlendirdikleri çalışmalarında kadınların gece emzirme sayısını ve gün içinde toplam emzirme süresini anlamlı olarak arttığı belirtilmiştir (18). Sağlıkta Dönüşüm Programı uygulanmaya başlamadan önceki dönemde Ergin ve ark. 2005 yılında Aydın'da lohusalık dönemini geçirmiş 806 kadınla yürüttüğü bir araştırmada evde ziyaret sıklığı \%59,9, ortalama ziyaret sayısı 2,0 01,7 olarak saptanmışlardır (16). Çatak ve ark. SDP sonrası DSB'yi değerlendirdikleri araştırmalarında ise aile hekimi/aile sağlığı elemanından DSB alan 
kadınların \%2,2'sinin DSB'yi evde aldığını bildirmişlerdir (13). SDP sonrası getirilen aile hekimliği modelinde hekim ve ebe başına düşen nüfusun yüksek olması nedeniyle evde anne ve bebek izlemleri yapılamamaktadır.

Bu çalışmada yalnızca bir kadın gebeliği boyunca hiçbir sağlık kuruma başvurmamış ve kadınların \%26,6'sı ASM'de gebelikleriyle ilgili hiç izlem yapılmadığını belirtmişlerdir. Gebelikte doğum öncesi bakım izlemlerinin performansa bağlı olduğu, izlenmeyen her bir gebe için aile hekimlerine ceza kesilmesi gerekliliği düşünüldüğünde bu sıklık çok yüksektir. Durusoy ve ark.'nın İzmir'de 2009 yılında devlet hastanelerine başvuran gebelerin aile hekimlerinde izlenme düzeylerini inceledikleri araştırmada ASM'de doğum öncesi bakım almayanların düzeyi \%15'tir (19). Sağlık Bakanlığı tarafından gebe, lohusa bebek ve çocuk sayılarının tam olarak tespit edilebilmesi, tüm anne ve bebeklerin yeterli sayıda ve kaliteli doğum öncesi ve sonrası sağlık hizmeti alabilmesi için geliştirilen bir proje olan Gebe, Lohusa, Bebek, Çocuk İzlem Sistemi'nin de (GEBLIZ) etkili olmadığı görülmektedir (20). Özel ya da kamu bir hastanede gebelik izlemi yapılan gebelerin ASM'de izlenmemesi birinci ve diğer basamaklar arasında eşgüdüm sorunu olduğuna işaret etmektedir.

ASM'de izlemin önemini destekler şekilde, hiç izlemi olmayanların \%20'sinde, en az bir izlemi olanların \%12,9'unda gebelik komplikasyonu gelişmiştir. Ayrıca üç kadında doğum sonu komplikasyon gelişmiştir. Konjenital anomaliye sahip bir, düşük doğum ağırlığı olan dokuz bebek dünyaya gelmiştir. Ergin ve ark. çalışmalarında lohusalık dönemi boyunca kadınların \%9,3'ünde $(n=75)$ herhangi bir komplikasyon geliştiğini bildirmişlerdir (16). Gebelerin kamuda birinci basamakta izlenmesi, erişimi olmayan gebelere evlerinde ulaşılması yasal olarak zorunlu ve anne ve bebek için istenmeyen sonuçları önleyebilmek için önemlidir.

$\mathrm{Bu}$ araştırmada hem doğum öncesi hem doğum sonrası izlemlerin ağırlıklı olarak özel sektörde yapıldığı gözlenmiştir. Özel hastanelerde kadınların cepten ödemesi gereken tutarlar düşünüldüğünde anne ve bebek ölümlülüğünün azaltılmasında etkisi bilinen bu hizmetlerin talebe bağlı sunulmaya başlandığı düşünülebilir. Buna karşın DSÖ, doğum öncesi ve doğum sonrası hizmetlerin kamu tarafından birinci basamakta sunulmasının hem hizmetin daha etkili ulaşmasını hem de toplumdaki eşitsizlikleri azalttığını vurgulamaktadır (21). Bu çalışmada doğum sonrası üç ve daha fazla izlemi olan kadın sayısı ilkokul ve altı eğitime sahip olanlarda en düşüktür. Evde ziyaretlerinin gerçekleşmesi, eğitim düzeyi düşük olanlar gibi dezavantajlı grupların kamuda sunulan ve ücretsiz olan hizmetlerden yararlanabilmesi açısından kritik öneme sahiptir.

Türkiye'de sezaryen ile doğum oldukça yüksek orandadır. TNSA 2013 verilerine göre ülkemizde doğumların \%48'i, Karabük ilinin de içerisinde bulunduğu Batı Karadeniz Bölgesi'nde ise doğumların \%56,5'i sezaryen ile gerçekleşmektedir (12). Sağlık Bakanlığı verilerine göre de 2016 yılında sezaryen doğumların tüm doğumlar içindeki payı \%53 olarak bildirilmektedir (22). Bu araştırmada sezaryen doğum sıklığı \%69,8 olarak bulunmuştur. Ülkemizde en yüksek eğitim ve refah düzeyindeki kadınlar için \%66 veya üzeri olan sezaryen oranı, en düşük eğitim ve refah düzeyinde sezaryenle gerçekleşen doğumların iki katından fazladır (12). Ülkemizde 2016 yılında sektörlere göre sezaryen sıklığı kamu hastanelerinde \%38 iken özel hastanelerde \%71'e yükselmektedir (22). DSÖ tarafından önerilen sezaryen oranın \%15 olduğu düşünüldüğünde (23) bu çalışmada saptanan yüksek sezaryen doğum sıklığı, Karabük'te doğumların \%61,5'inin özel sağlık kuruluşunda gerçekleşmesi ile açıklanabilir. TNSA 2013'e göre ülkemizde doğumların \%37'si özel sektörde gerçekleşmektedir (12).

Çalışmada annelerin \%81,7'sine bağışıklama takvimi, \% 53,3'ine anne sütü ve emzirme, \% 43,8'ine bebek bakımı, \% 42,6'sına beslenme, \% 36,7 'sine aile planlaması ve \% 36,1'ine doğum sonu tehlike belirtileri konusunda bilgi verilmiştir. Çatak ve ark.'larının çalışmasında DSB alan kadınlara aile hekimi/aile sağlığı elemanı doğumdan sonraki ilk iki ay içinde en fazla emzirme $(\% 88,2)$ ve gebelikten korunma yöntemlerine $(\% 72,7)$ ilişkin bilgi vermiştir (13). Bu çalışmada birinci basamak sağlık hizmetleri kapsamında ele alınan iki temel DSB hizmeti olan emzirme ve aile planlaması Çatak ve ark.'larının çalışmasına kıyasla oldukça düşüktür. Yine Çatak ve ark.'larının çalışmasında kadın doğum uzmanları tarafından verilen hizmetler sırasıyla karın muayenesi $(\% 85,1)$, kanama kontrolü $(\% 73)$, kan basını ölçümü $(\% 63,8)$, ateş ölçümü $(\% 40,8)$, kan tetkiki $(\% 13,1)$, idrar tetkiki $(\% 11,1)$ şeklindedir (13). Bu çalışmada kadınlar hastanede iken fundus 
yüksekliği ve kanama kontrolü, kan basıncı ve ateş ölçümü düzeyleri \%90'nın üzerinde, kan ve idrar tahlillerinin oranı \%40-50 düzeyindedir. Ancak anneler hastaneden çıktıktan sonra yapılan ölçüm ve muayenelerin çok düşmektedir. Bu durum, annelerin çoğunlukla bebekleri için tarama, aşı gibi hizmetleri almak üzere sağlık kuruluşuna başvurduğu için anneye yönelik değerlendirmelerin yapılmadığı şeklinde yorumlanabilir.

Çalışmada, doğum sonu üç ve fazla sayıda izlemi etkileyen en önemli etmenlerden biri doğum öncesi alınan izlem sayısıdır. Sayıları az olmakla beraber doğum öncesi üç ve daha az izlenen kadınlar arasında üç ve daha fazla doğum sonu izlemi olan kadın bulunmamaktadır. Gebrehiwot ve ark.'Iarının Etiyopya'da DSB hizmetlerinin kullanımını etkileyen faktörleri incelediği çalışmada da DÖB almanın DSB almayı beş kata kadar arttırdığı bildirilmiştir (9).

Doğum sonu izlemi etkileyen bir diğer etmen, doğum öncesi gebelere verilen eğitimdir. Doğum sonrası bakım sıklığını ve hizmetin niteliğini artırmak için başta eğitim olmak üzere bazı müdahale çalışmaları yapılmaktadır. Hanfield ve Bell'in Avusturalya'da doğum öncesi eğitim sınıflarının doğum sırasında ve sonrası dönemde oluşan sorunlara ilişkin tutuma etkisini araştırdıkları çalışmada kadınların eğitim sonrasında doğum sonu komplikasyonlar ve emzirme sorunları ile ilgili hizmet alma eğilimlerinin arttığı bildirilmiştir (24). Serçekuş ve Mete'nin İzmir'de doğum öncesi eğitimin etkisi üzerine yaptıkları çalışmada ise DSB hizmet alımına dair bir veri olmasa da eğitim alan kadınların doğum sonrası döneme dair bilgi ve farkındalık düzeylerinin arttığını tespit etmişlerdir (25). Buna karşın Schachman ve ark. ABD'de gebelere doğum öncesi eğitim müdahalesi yaparak gerçekleştirdikleri çalışmalarında eğitimi alan ve almayan grupta DSB hizmeti alma açısından anlamlı bir fark olmadığı bildirmişlerdir (26). Bu durum doğum sonrası erken dönemde kadınların hizmet almaya daha eğilimli olması ancak aradan geçen zamanda eğitim almış olan kadınların izlemlere gitme oranının yüksek olması ile açıklanmıştır (26).

\section{Sonuç}

Çalışma, doğum öncesi ve doğum sonu dönemde ev ziyareti yapılan kadın bulunmadığını, bakım hizmetlerinin talebe dayalı yürütüldüğünü, doğum sonu dönemde annelerin kontrol ve bakımının büyük ölçüde hastanede yattığı süreyle sınırlı kaldığını, gebe ve lohusalara verilen hizmetlerde birinci basamağın ağırlığı azalırken özel sektörün ağırığının arttığını göstermektedir. Doğum sonu bakımı artıran en önemli etmenlerden birinin doğum öncesi gebelerin aldığı eğitimler olduğu ve bu eğitimleri kadınların neredeyse yarısının almadığı düşünüldüğünde, birinci basamakta bu eğitimlerin her gebeye ulaşacak şekilde yaygınlaştırılması doğum sonu bakımın niteliğini arttıracaktır. Birinci basamak hizmetlerinin toplumun gereksinimlerine dayalı kapsamlı ve sürekli olacak biçimde geliştirilmesi, anne ve bebek sağlığının korunmasının temel koşuludur.

\section{Kaynaklar}

1. who.org. Geneva: WHO recommendations on Postnatal care of the mother and newborn 2013 [updated October 2013; cited 9 July 2018]. Available from: http://www.who.int/maternal_child_adolescent/documents/postnatalcare-recommendations/en/

2. who.org. Geneva: WHO technical consultation on postpartum and postnatal care [updated 29 October 2008 ; cited 9 July 2018]. Available from:

http://apps.who.int/iris/bitstream/handle/10665/70432/WHO_MPS_10.03_eng.pdf?sequence=1\%0Ahttp://www.who.int/ maternal_child_adolescent/documents/WHO_MPS_10_03/en/

3. Kikuchi K, Ansah EK, Okawa S, et al. Effective linkages of continuum of care for improving neonatal, perinatal, and maternal mortality: A systematic review and meta-analysis. PLoS One 2015; 10 (9): 1-27.

4. Darmstadt GL, Bhutta ZA, Cousens S, Adam T, Walker N, Bernis LD. Series: Evidence-based, cost-effective Interventions: how many newborn babies can we save? Lancet 2005; 365 (3): 977-88.

5. Langlois ÉV, Miszkurka M, Zunzunegui MV, Ghaffar A, Ziegler D, Karp I. Inequities in postnatal care in low- and middle-income countries: a systematic review and meta-analysis. Bull World Health Organ 2015; 93 (4): $259-70$.

6. Mwase T, Brenner S, Mazalale J, et al. Inequities and their determinants in coverage of maternal health services in Burkina Faso. Int J Equity Health 2018; 17 (1):1-14. 
7. worldbank.org. Socio-economic differences in health, nutrition, and population within developing countries [updated September 2007; cited 9 July 2018]. Available from: https://siteresources.worldbank.org/INTPAH/Resources/IndicatorsOverview.pdf

8. Smith LFP. Postnatal care: development of a psychometric multidimensional satisfaction questionnaire. British Journal of General Practice 2011; 61 (591): e628-37.

9. Gebrehiwot G, Medhanyie AA, Gidey G, Abrha K. Postnatal care utilization among urban women in northern Ethiopia: Cross-sectional survey. BMC Womens Health 2018; 18 (1):1-10.

10. Dennis ML, Abuya T, Campbell OMR, et al. Evaluating the impact of a maternal health voucher programme on service use before and after the introduction of free maternity services in Kenya: a quasi-experimental study. BMJ Glob Heal 2018;3(2):e000726.

11. saglik.gov.tr. Ankara: Türkiye Halk Sağlığı Kurumu Kadın ve Üreme Sağlığı Daire Başkanlığı Doğum Sonu Bakım Yönetim Rehberi [updated 2014; cited 9 July 2018]. Available from: https://sbu.saglik.gov.tr/Ekutuphane/kitaplar/dsbyr_2.pdf

12. hips.hacettepe.edu.tr. Ankara: Hacettepe Üniversitesi Nüfus Etütleri Enstitüsü (2014), "Türkiye Nüfus ve Sağlık Araştırması (2013)" [updated 2014; cited 20 July 2018]. Available from: http://www.hips.hacettepe.edu.tr/tnsa2013/rapor/TNSA_2013_ana_rapor.pdf

13. Çatak B, Sütlü S, Kılınç AS, Badılıoğlu O, Zencir M. Burdur 'da 2009 yııında doğum yapmış kadınların doğum özellikleri ve doğum sonu bakım hizmetleri. TAF Prev Med Bull 2011; 10 (5): 579-86.

14. Altuntu K, Ege E. Sağlık eğitiminin annelerin taburculuğa hazır oluş, doğum sonu güçlük yaşama ve yaşam kalitesine etkisi. Hemşirelikte Araştırma Geliştirme Dergisi 2013; 9557 (2): 45-56.

15. Hacettepe Üniversitesi Nüfus Etütleri Enstitüsü, ICON-INSTITUT Public Sector GmbH ve BNB Danışmanlık (2006) Ulusal Anne Ölümleri Çalışması, 2005. Sağlık Bakanlığı Ana Çocuk Sağlığı ve Aile Planlaması Genel Müdürlüğü ve Avrupa Komisyonu Türkiye Delegasyonu, Ankara.

16. Ergin $F$, Başar P, Karahasanoğlu B, Beşer E. Güvenli olmayan doğumlar ve doğum sonrası evde bakım hizmetlerinin değerlendirilmesi. TSK Koruyucu Hekimlik Bülteni 2005;4(6):321-29.

17. Kenny P, King MT, Cameron S, Shiell A. Satisfaction with postnatal care: the choice of home or hospital. Midwifery 1993; 9 (3):146-53.

18. Erenel A, Eroğlu K. Doğum sonrası ilk altı ayda ev ziyareti yoluyla desteklenen emzirme eğitimi modelinin etkill emzirme davranışı üzerine etkisi. Hacettepe Üniversitesi Hemşirelik Yüksekokulu Dergisi 2005;12(2):43-54.

19. Durusoy R, Davas A, Ergin I, Hassoy H, Tanık FA. İzmir'de ikinci ve üçüncü basamak sağlık kuruluşlarına başvuran gebelerin aile hekimi tarafından izlenme sıklıkları ve etkileyen etmenler. Turkish Journal of Public Health, 2011; 9 (1), 1-15.

20. Kartal SB, Birler AG, Ozkul D ve ark. The Improvement of Prenatal, Postnatal, Newborn and Preschool Child's Health Care Services in Istanbul: GEBLIZ. TAF Prev Med Bull 2010;9(4):289-96.

21. who.org. Geneva: The World Health Report 2008. Primary health care: Now more than ever [updated 2008; cited 11 July 2018]. Available from: http://www.who.int/whr/2008/whr08_en.pdf

22. saglik.gov.tr. Ankara: Sağlık Bakanlığı Sağlık Araştırmaları Genel Müdürlüğü Sağlık İstatistikleri Yıllığı 2016. [updated 20.12.2017; cited 19 July 2018] Available from: https://dosyasb.saglik.gov.tr/Eklenti/13183,sy2016turkcepdf.pdf?0

23. saglik.gov.tr. Ankara: Sağlık Bakanlığı Ana Çocuk Sağıı̆ı ve Aile Planlaması Genel Müdürlüğü. Doğum ve Sezaryen Eylemi Yönetim Rehberi [updated 2010; cited 20 June 2018]. Available from: https://dosyaism.saglik.gov.tr/Eklenti/8983,dogum-ve-sezaryen-eylemi-yonetim-rehberipdf.pdf?0

24. Handfield B, Bell R. Do childbirth classes influence decision making about labor and postpartum issues? Birth 1995; 22 (3):153-60.

25. Sercekus P; Mete S. Turkish women's perceptions of antenatal education. Int Nurs Rev 2010; (2005): 395-402.

26. Schachman KA, Lee RK, Lederma RP. Baby Boot Camp: facilitating maternal role adaptation among military wives. Nurs Res 2004; 53 (2): 107-15. 